\title{
On the Geographic Distribution of Death Rates from Vascular Lesions Affecting the Central Nervous System in the United States An Epidemiological Hypothesis
}

By

\author{
Eiji Takahashi
}

From the Department of Hygiene, Tohoku University School of Medicine, Sendai

(Received for publication, October 31, 1961)

There is a great difference between Japan and most Western countries in the pattern of death rates from vascular lesions affecting the central nervous system and death rates from heart disease. In Japan the central nervous system rates are much higher than the heart disease rates and are a most important cause of death numerically. In most Western countries heart disease rates are much higher than central nervous system rates, and the central nervous system rates are much lower than those recorded in Japan. Although it may be probable that the difference is ascribed to differences in diagnosis to a certain extent, it should be considered that the big difference in the living conditions, especially in diet, is a main cause of the difference of the death rates.

Furthermore, in Japan, there is some geographic difference in the presenile (45-64 years of age) death rates from vascular lesions affecting central nervous system. The northeast part of Honshu, the main island of Japan, shows the highest death rate from cerebral hemorrhage in Japan. We have studied the blood pressure levels and living conditions of rural inhabitants in this area. Although this study is still in progress, certain preliminary results ${ }^{1,2}$ ) suggest that environmental temperature (especially indoors) and dietary customs are the most important etiological factors in both hypertension and cerebral hemorrhage in this area.

A peculiar distribution of death rates from vascular lesion affecting central nervous system is found also in the U.S. from the data of governmental Vital Statistics ${ }^{3}$. As shown in Figure 1, the presenile (45-64) death rate from cerebral hemorrhage is extraordinarily high in the Southeastern states as compared with the states in other parts of the country. Rates outside the Southeastern states vary between 50 and 100, while South Carolina and Georgia show rates exceeding 200 , similar to the rates recorded in some prefectures in Japan. 


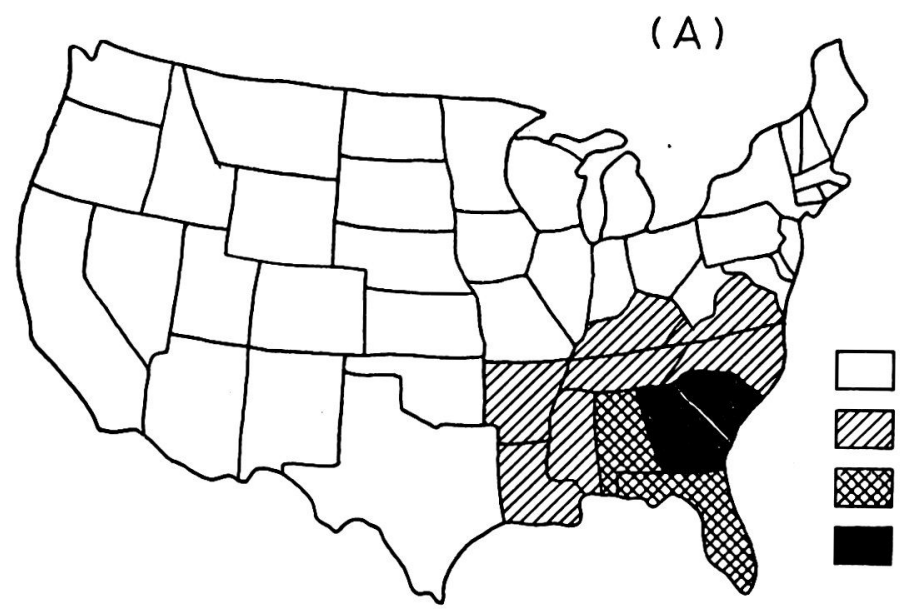

Presenile Death Rote per 100,000 Popl. (45-64) $50.0-99.9$ $100.0-149.9$ $150.0-199.9$ $200.0-249.9$

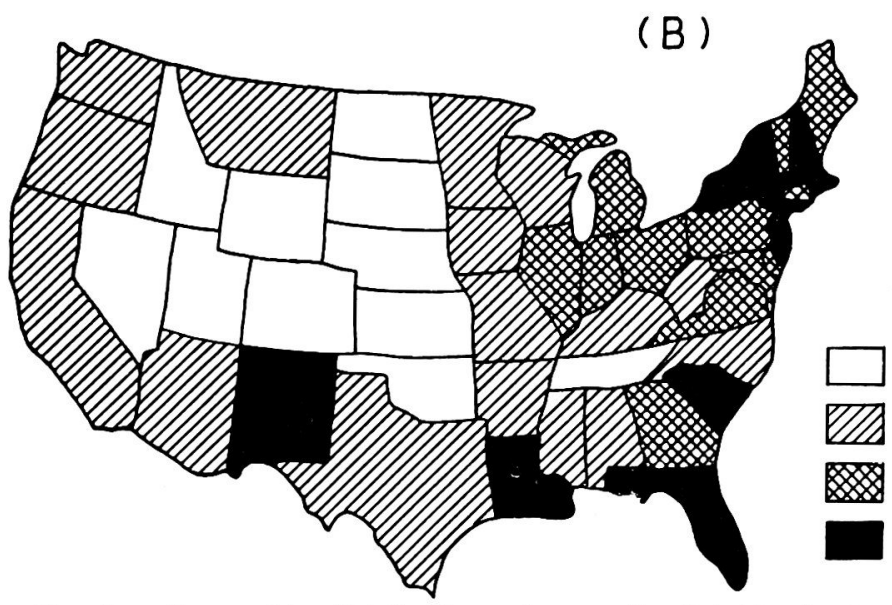

Presenile Death Rate per 100,000 Popl. (45-64) $250.0-299.9$ $300.0-349.9$ $350.0-399.9$ $400.0-449.9$

Fig. 1. Geographic distribution of presenile (45-46) death rate from vascular lesions affecting central nervous system (A), and from arteriosclerotic heart disease including coronary disease (B). Male and female, U.S.A., 1958.

This geographic concentration of high death rate states for cerebral hemorrhage contrasts with the distribution of arteriosclerotic heart disease, in which high death rate states are primarily concentrated in the Northeast.

In the present article "cerebral hemorrhage" will be used for all vascular lesions affecting central nervous system to abbreviate the nomenclature.

Etiological considerations concerning the higher prevalence of cerebral hemorrhage in the Southeast.

Of course, the population of these Southeastern states contains a large proportion of Negroes, and the correlation coefficient between the presenile death rate from cerebral hemorrhage and the percentage of Negroes in the population by 
state is significant $(n=49, r=0.766)$, though the distribution of the death rate is not normal. Lennard and Glock" have noted that "the mortality of Negro males and females from hypertension, with or without mention of heart disease, is higher than that of white males and females for every age group, especially for 30-55". They have proposed the following four hypotheses to explain this racial difference: the genetic hypothesis, the physical exertion hypothesis, the psychosomatic hypothesis, and the associated disorder hypothesis. I would like to suggest a different hypothesis regarding the higher death rate from cerebral hemorrhage in the Southeastern states, especially for those of Negroes, though I have no personal knowledge of their real living conditions.

As regards the racial constitution hypothesis, it might be correct, as Phillips and Burch" have stated that "the Negro is much more adaptable to the hot, humid environment than is the white man but is much less adaptable to the cold environment than the white". These authors also noted that responses to the cold pressor test suggested that the vasomotor mechanism in the Negro was more sensitive than in whites and that racial differences were apparent in the electrolyte composition of erythrocytes, Negroes having a higher sodium concentration than whites in one study involving a total of 105 individuals.

Though it seems that the death rates for cerebral hemorrhage by states are highly correlated to the percentage population of Negroes, in the District of Columbia, where the percentage of Negro population is as high as in South Carolina and Georgia, the death rate from cerebral hemorrhage is not so high. The same tendency will also be seen in Mississippi, which has the highest proportionate Negro population $(45.3 \%)$.

At the same time, those states which show the high death rates for cerebral hemorrhage belong in almost all cases to low income geographic areas. As shown in Table $\mathrm{I}^{6)}$, almost all these states in the Southeast, except Maryland, which seems to be more similar to the Northeast, show median incomes below $\$ 2000$ for whites and below $\$ 1000$ for non-whites, contrary to the Middle Atlantic and East North Central States, where median incomes of whites are over $\$ 2000$ and of non-whites over $\$ 1000$.

As seen in Figure 2, which gives death rates for vascular lesions affecting the central nervous system in the age group 55-64 by color and sex taken from the data of the vital statistics special reports of $1959^{7}$ ), higher death rates for this cause in the Southeast are found not only in Negroes but also in whites. In the West non-whites show a lower death rate from cerebral hemorrhage than in the other divisions, and here the rate is nearly as low as that of the whites. In this region non-whites include not only Negroes but also other races, Indians, Chinese and Japanese, in considerable percentage. (According to the result of the 1950 census, over $2 / 3$ of the non-white group in California is composed of Negroes).

Also the blood pressure level of male Negro employee of Los Angeles city 
TABLE I. Median Income in 1950 by Color in the Northeast, Central and South.

\begin{tabular}{|c|c|c|c|}
\hline \multirow{2}{*}{ Division } & \multirow{2}{*}{ State } & \multicolumn{2}{|c|}{ Median Income in 1950} \\
\hline & & White & Non-White \\
\hline $\begin{array}{l}\text { Middle } \\
\text { Atlantic }\end{array}$ & $\begin{array}{l}\text { N. Y. } \\
\text { N. J. } \\
\text { Penn. }\end{array}$ & $\begin{array}{l}2,401 \\
2,464 \\
2,162\end{array}$ & $\begin{array}{l}1,693 \\
1,531 \\
1,527\end{array}$ \\
\hline $\begin{array}{c}\text { East North } \\
\text { Central }\end{array}$ & $\begin{array}{l}\text { Ohio } \\
\text { Ind. } \\
\text { Ill. } \\
\text { Mich. }\end{array}$ & $\begin{array}{l}2,252 \\
2,140 \\
2,393 \\
2,441\end{array}$ & $\begin{array}{l}1,607 \\
1,625 \\
1,811 \\
2,175\end{array}$ \\
\hline $\begin{array}{l}\text { South } \\
\text { Atlantic }\end{array}$ & $\begin{array}{l}\text { Md. } \\
\text { Va. } \\
\text { W. Va. } \\
\text { N. C. } \\
\text { S. C. } \\
\text { Ga. } \\
\text { Fla. }\end{array}$ & $\begin{array}{l}2,261 \\
1,880 \\
1,859 \\
1,567 \\
1,684 \\
1,515 \\
1,737\end{array}$ & $\begin{array}{r}1,184 \\
919 \\
1,531 \\
712 \\
525 \\
610 \\
847\end{array}$ \\
\hline $\begin{array}{c}\text { East South } \\
\text { Central }\end{array}$ & $\begin{array}{l}\text { Ky. } \\
\text { Tenn. } \\
\text { Ala. } \\
\text { Miss. }\end{array}$ & $\begin{array}{l}1,411 \\
1,374 \\
1,455 \\
1,236\end{array}$ & $\begin{array}{l}862 \\
799 \\
616 \\
439\end{array}$ \\
\hline $\begin{array}{l}\text { West South } \\
\text { Central }\end{array}$ & $\begin{array}{l}\text { Ark. } \\
\text { La. } \\
\text { Tex. }\end{array}$ & $\begin{array}{l}\text { I, } 117 \\
1,767 \\
1,754\end{array}$ & $\begin{array}{l}488 \\
774 \\
817\end{array}$ \\
\hline
\end{tabular}

The 21 states are those states having (a) more than 100,000 non-white population, and (b) 90 per cent of the non-white population Negro, in 1950. Standardization is to the total United States population, 1950. (MacMahon, B. \& Koller E.K. : J. Hematology, 12, 1-10, 1957).

(mean blood pressure of 86 Negroes aged $40-54$ is $132 / 82 \mathrm{~mm} \mathrm{Hg})^{8 \text { ) }}$ is not so high as that of male Negroes in Nassau in Bahamas (mean blood pressure of 67 aged $40-44$ is $142 / 91 \mathrm{~mm} \mathrm{Hg}, 67$ aged 45-49 145/94, and 37 aged 50-54 156/93)' and of male Negroes in Virgin Islands (mean blood pressure of 122 aged $40-44$ is $143 / 88 \mathrm{~mm} \mathrm{Hg}, 139$ aged 45-49 $150 / 90$, and 133 aged $50-54150 / 91)^{10}$.

It may be seen in Figure 2 that there is a geographic difference in death rates from cerebral hemorrhage not only in non-whites but also in whites and that the geographic distribution of the death rates of non-whites and whites seem to be parallel, though the range of the rates is smaller in whites than in non-whites. Nutritional hypothesis

With regard to the distribution of death rates from cerebral hemorrhage I would suggest that some environmental factor, in particular a nutritional factor, would seem to be more important than the racial factor.

It should be remembered that these Southeastern states belonged to a pellagra prevailing area in the early 1920's. It seems that the dietary defect and 

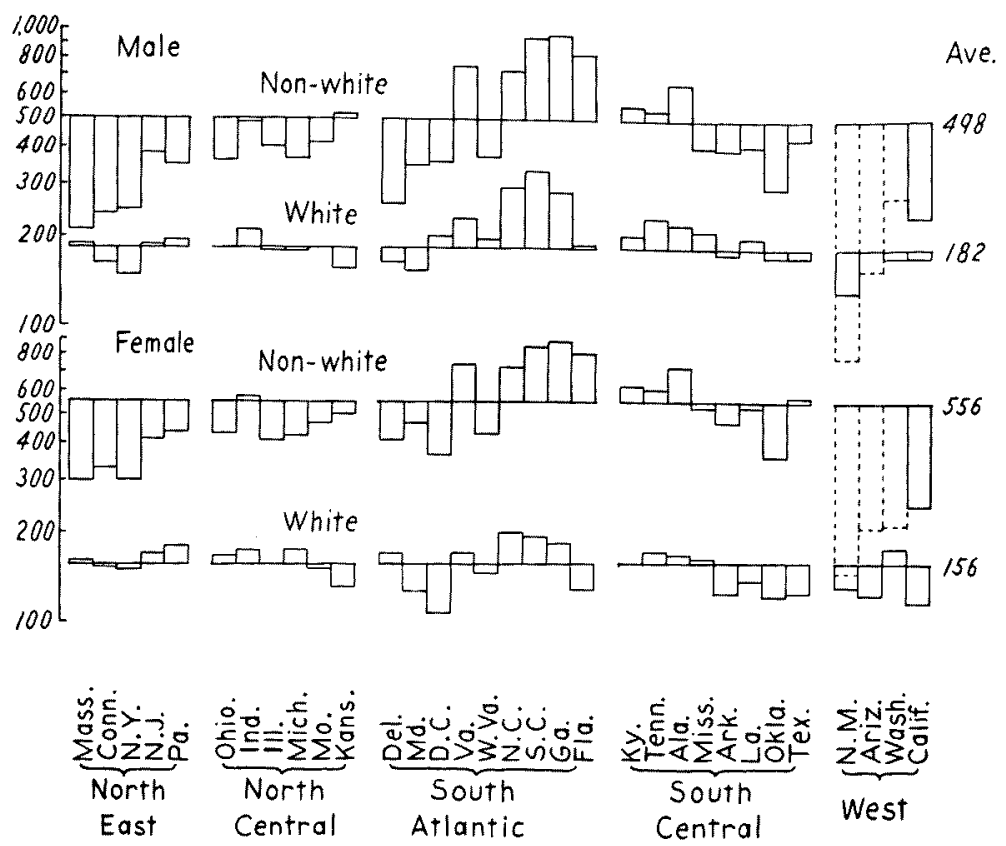

Fig. 2. Death rate for vascular lesions affecting central nervous system of 55-64 age group by color and sex (per 100,000 population).

nutritional deficiency in the past several decades as well as that at present might be epidemiologically important for such chronic diseases as hypertension, cerebral hemorrhage and arteriosclerotic heart disease. The situation is changed to a considerable degree at present, but the death rate from pellagra in each five years of 1953-57 and 1947-51 distribute relatively higher in the Southern states, and the figure is very similar to that of cerebral hemorrhage, as shown in Fig. 3. (Race and sex distribution of 96 pellagra deaths in the U.S. in 1955 ; white male 20, female 46 ; Negro male 7, female 23 . Age distribution ; 25-94, especially 55-89).

It is a social principle in general that in the low income class cereals comprise the bulk of the diet, since these are the cheapest of all foods. These diets include lesser proportions of vegetables and fruit as well as meat and milk.

According to the report "Family food consumption is three types of farming areas of the South"11, which was based on weekly food records in the late winter and early spring of 1948, "diets of farm families (especially of Negro families) in this season fell more often and more seriously below NRC recomended allowances in respect to calcium, vitamin $A$ value and ascorbic acid than in other essentials. Among families of the low economic groups protein and riboflavin were often limiting factors also." "Farm families in these areas use comparatively little milk, few eggs, and rather small quantities of certain vegetables and fruits if they 

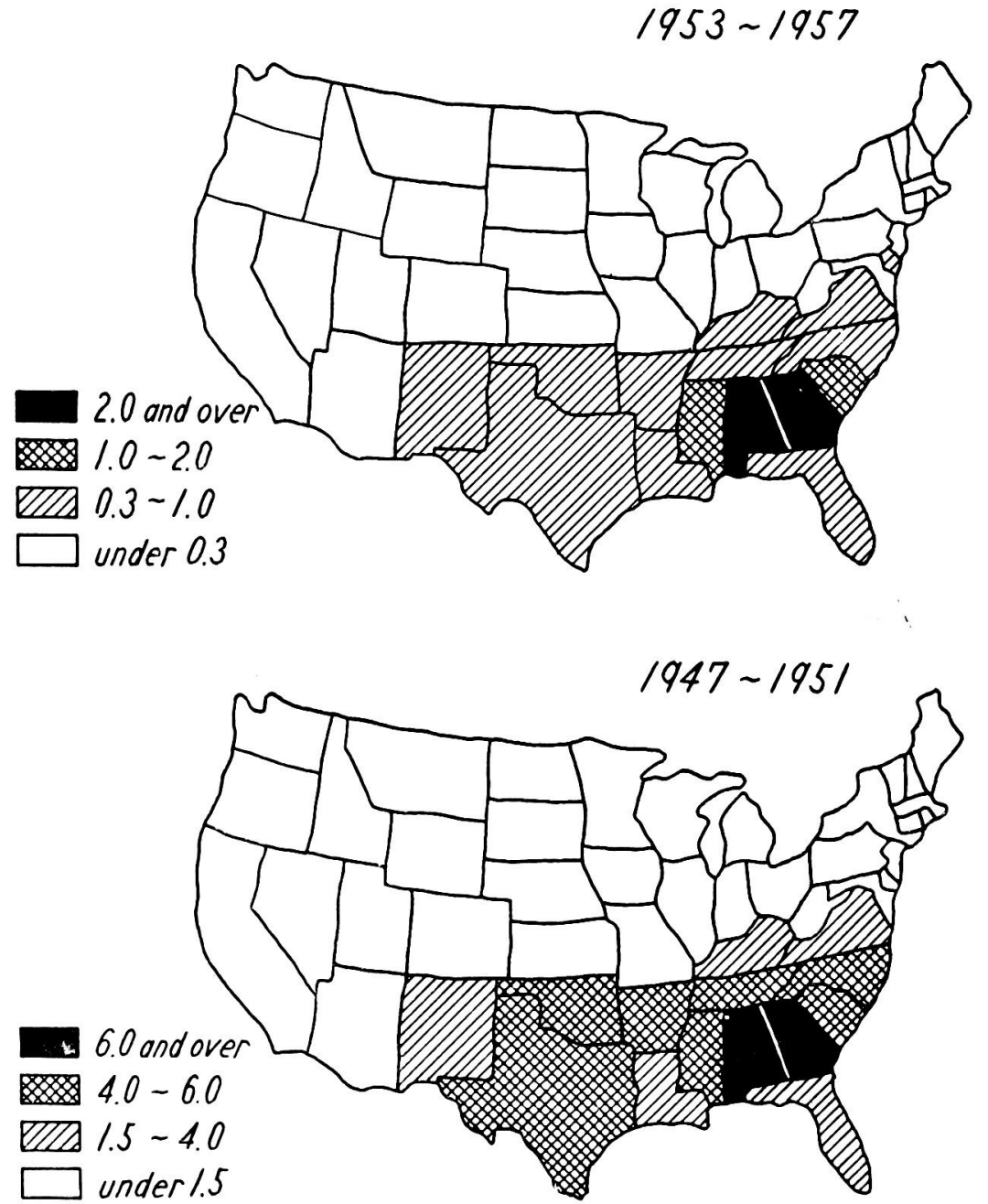

Fig. 3. Geographic distribution of death rate from pellagra in each 5 years of 1953-1957 and 1947-1951, male and female.

were not produced on the farm". The Bureau of Human Nutrition and Home Economics ${ }^{12)}$ found that "the most limiting nutrients in food supplies of families in both Georgia and Ohio counties were calcium, vitamin A value, and ascorbic acid. Dietary shortages were more frequent among families in the Georgia county than among those in the Ohio county."

Schroeder ${ }^{13)}$ who had followed the work of Kobayashi14) in Japan had recently found highly significant negative correlations between the hardness of water and the cardiovascular mortality for white men aged 45 to 64 in the U.S. 
Morris et al. ${ }^{15}$ ) had followed this work in England and had found a significant correlation of the water hardness with the mortality of cerebrovascular disease as well as myocardial degeneration. The correlation is high for calcium content, in remarkable contrast with magnesium.

It might be easier to consider that the hardness of water should manifest its effect on arterial tissue when the water is drunk and the compound of the mineral is absorbed through the mucous membrane of digestive canal. But the shortage of minerals, especially calcium in food taken in should be more important than in the drinking water.

According to Zweifach"1), "in dividing marine ova and in sheets of cells in tissue culture, there is good evidence for the existence of a cement material which was both $\mathrm{pH}$ and calcium dependent. On the acid side of the $\mathrm{pH}$ range and in the presence of calcium-deficient media, the contiguous cells no longer adhered to one another, became detached, and frequently began to exhibit an ameboid motion. In view of the near identity of the action of $\mathrm{pH}$ changes and calcium deficiency on the integrity of the endotherial wall, it was postulated that an analogous cement material was present in vascular endothelium."

It has to be considered, that the vitamins of B-complex are components of the enzymes or co-enzymes which are necessary for oxidation and decomposition of carbohydrates and fats in vivo. Therefore, a deficiency of vitamin B-complex will also produce intermediate products of metabolism of carbohydrates, fats and it is probable that the $\mathrm{pH}$ range of the body fluid declines to the acid side.

In Japan, especially in the Northeast rural area, where farm villagers take a large amount of polished rice with much salt but with small amounts of vegetables, there are found many hypertensives, and the death rate from cerebral hemorrhage is the highest of all districts of Japan.

The hypothesis that the main cause of the higher prevalence of cerebral hemorrhage in the Northeastern district of Japan is the excessive intake of rice may be surprising in the United States, where the Kempner rice-fruit diet therapy for hypertension is most common. However, this diet contains 5,000 I.U. of vitamin $A, 1,000$ I.U. of vitamin $D, 5 \mathrm{mg}$. each of vitamins $B_{1}$ and $B_{3}$, $25 \mathrm{mg}$. of nicotinic acid, $2 \mathrm{mg}$. of $\mathrm{Ca}$-pantothenic acid, and less than $1 \mathrm{mg}$. of $\mathrm{NaCl}$, besides $2,000 \mathrm{Cal}$., $20 \mathrm{gm}$. of protein and less than $5 \mathrm{mg}$. of fat from rice, a fair amount of sugar and fruit juice ${ }^{17}$. These vitamins are lacking in the diet of the Northeastern rural districts of Japan, and in these districts farmers take about $20 \mathrm{gm}$. of salt a day.

According to the result of National Nutritional Survey of Japanese Government, the avvage calcium intake of the nation in 1960 was $389 \mathrm{mg}$. per person per day (in rral district lower than this value), in contrast with $1330 \mathrm{mg}$. of phosphorus, and it is lower not only than the average intake of inhabitants in the New England and Middle Atlantic states ${ }^{18)}$, but also than that among the Negroes 
in the cotton or tobacco farm area in the South ${ }^{11,12)}$, and just the same as in Jamaican lower income families ${ }^{10)}$.

With respect to death rates from cerebral hemorrhage Negroes in the Southeastern states of the United States seem somewhat similar to the rural inhabitants in the Northeastern part of Japan.

Of course, in some Southeastern states, such as South Carolina, Florida, and Louisiana, the death rate is high not only for vascular lesions affecting the central nervous system but also for arteriosclerotic heart disease. The arteriosclerotic heart disease death rates are also high in the states of New England, New York and New Jersey. However, in the latter group of states the death rate from vascular lesions affecting the central nervous system is not so high as in the Southeastern states, where the high death rates for vascular lesions affecting the central nervous system are very characteristic.

It seems that the etiologic factors responsible for hypertension in the two different areas, the Southeastern states and the Northeastern states, may be different to some extent. In the Northeastern states the main cause of hypertensive disease, especially of heart disease, may be the dietary pattern of the Western countries, which is rich in animal protein and fat, in addition to psychological factors associated with the complex social life and a factor of lack of exercise associated with the sedentary work pattern. A significant correlation $(\mathrm{n}=48, \mathrm{r}=0.48)$ is found between the presenile death rate from arteriosclerotic heart disease and the per cent of population classified as urban, by states. This is in contrast with the presenile death rates from cerebral hemorrhage by states, which do not show a significant correlation with per cent of urban population.

\section{SUMMARY}

The peculiar distribution of the presenile (45-64) death rates from the vascular lesions affecting the central nervous system in the United States is epidemiologically discussed. As an etiological factor of it, the nutritional hypothesis is suggested for the high incidence of the vascular lesions affecting the central nervous system in the Southeastern states, especially of Negroes.

In the Southeast, where there are more people of low income class than in the Northeast, the prevailing diet is one of cereals, lacking in vegetables and fruit as well as meat and milk. Consequently, some vitamin deficiency should result, especially of A,C, and B-complex as well as calcium deficiency. These nutritional deficencies might be considered as an etiological factor of the high incidence of the vascular lesions affecting the central nervous system in the Southeast of the United States as well as in Japan.

\section{Literature}

1) Takahashi, E. et al, Human Biology, 1957, 29, 139.

2) Takahashi, E. et al., Tohoku J. Exp. Med., 1961, 74, 188. 
3) U.S. Dept. of Health, Education, and Welfare, Vital Statistics of the United States, 1958.

4) Lennard, H.L. \& Glock, C.Y., J. Chron. Dis., 1957, 5, 186.

5) Phillips, J.H. \& Burch, G.E., Medicine, 1960, 39, 241.

6) MacMahon, B. \& Koller, E.K., J. Hematology, 1957, 12, 1.

7) U.S. Dept. of Health, Education, and Welfare, Vital Statistics Special Reports, 1959, Vol. 49, No. 32 .

8) Chapman, J.M., The Los Angeles Heart Study-1959 Progress Report.

9) Johnson, B.C. \& Remington, R.D., J. Chron. Dis,, 1961, 13, 39.

10) Saunders, G.M. \& Bancroft, H., Amer. Heart J., 1942, 23, 410.

11) Sonth Carolina Agricultural Experiment Station, Southern Cooperative Series Bulletin, 1951, No. 20.

12) U.S. Department of Agriculture, Miscellaneous publication, 1950, No. 704.

13) Schroeder, H.A., J. Amer. Med. Ass., 1960, 172, 1902.

14) Kobayashi, J., Berichte Ohara Inst. f. Landwirts. Biol., 1957, 9, No. 1.

15) Morris, J.N. et al., Lancet, 1961, I, 860-862.

16) Zweifach, B.W., "The arterial wall" edited by Lansing, 1959, Williams \& Wilkins Co., Balt.

17) Kempner, W., Amer. J. Med., 1948, 4, 545.

18) Rhode Island Agricultural Experiment Station, Northeast Regional Publication, 1952, No. 11 .

19) Gourlay, I. \& Miall, W.E., personal communication. 